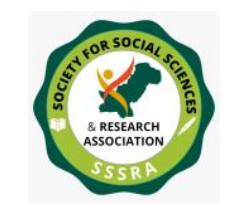

\title{
CAUSES AND IMPACTS OF TERRORISM IN SWAT VALLEY (2007-2017)
}

\author{
Muhammad Fahim Khan \\ PhD Scholar \\ Department of Political Science \\ University of Peshawar \\ Peshawar - Pakistan \\ fahimkhanjadoon86@gmail.com \\ Dr. Muhammad Ayaz Khan \\ Head, Department of Political Science \\ Hazara University \\ Mansehra - Pakistan \\ drmuhammadayazkhan@gmail.com
}

\begin{abstract}
Terrorism is a universally contested concept with varying understanding in different regions of the world. Its conceptualization in developed countries and developing countries is different in the essence of perception and operationalization. This study attempts to explore the genesis of terrorism generally in Pakistan and Swat valley in particular. It explores the causes and major driving forces of terrorism and the factors which contributed to its spread because of social fault lines. The menace of terrorism had been globalized in the wake of 9/11, which led the US to initiate global war on terror, but its implications on Pakistan were triggered by the US invasion of Afghanistan and the contributions of Pakistan in this regard. The global geographic attraction of Pakistan makes it vulnerable to any critical development in the world by default. To analyze the causes and impacts of the study, this study relies on a descriptive method of analysis backed by primary and secondary data in a bid to provide more diversity for a broader understanding of the outcome. This study found out multiple factors including weak social fabric, political instability, the grim economic situation of masses, poor education and health facilities, and above all, lack of social justice responsible for instigating violence in the region and urge to challenge the writ of the state, this study further debates on the losses incurred to inhabitants with the destruction of civil infrastructure. Pakistan lost approximately 35000
\end{abstract}




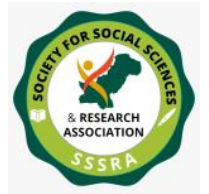

Pak. Journal of Int'L Affairs, Vol 4, Issue 1 (2021)

Causes and Impacts of Terrorism in Swat ...

civilians and 7000 military personnel in the war on terror in exclusion to the loss of the economy in this particular area. This study efforts to suggest concrete steps to improve security conditions in the area to foster socio-economic development in the region and provide adequate facilities and living standards.
\end{abstract}

Keywords: Pakistan, Terrorism, Swat Valley, Afghanistan, Socio-Economic Development.

\title{
Introduction
}

The outbreak of terrorism in the Swat valley was the byproduct of war on terror. It also focuses on the spread of terrorism and the rise of their stronghold in the Swat valley. However, Tehrik-e-Taliban Pakistan has been constituted a major resisting force in Swat valley. This group had been widely known for the fundamental belief of Islam, which they try to enforce in Swat discarding every social custom and state law in the area. In a bid to prevent their rise, the Pakistan military had to execute military operations in larger civilian interests and forced the terrorists to flee the area.

Meanwhile, Pakistan joined the Global War on Terrorism led by the USA and made extensive efforts to eradicate terrorism. However, the Pakistani administration eradicates terrorism from the Swat region, but they lost many lives of their soldiers and civilians, which left a significant impact on the life of Swati people. The method which is used to formulate the research is historical and descriptive, and the unstructured interview method is used to get in-depth information about the relevant topic. However, the sensitivity of the issue remains in view.

\section{Historical Perspective of Terrorism in Swat}

However, after the incident of 9/11, TNSM leader arrested during his effort to fight against coalition forces in Afghanistan. His arrest cooled down the TNSM movement of militancy. His son-in-law sooner filled this gap Fazal Hayat named Fazalullah. He was born in a farming family of Swat village Man Dheri in 1947. In 1990 to show his spiritual affiliation with religion, he changed his name to Maulvi Fazalullah. He did not join any educational or religious institution to get an education; thus, he had no credential showing his educational carrier. The only credit on his side was that he took part in Jihad against NATO forces in Afghanistan, along with his father-in-law Sufi Muhammad. He was arrested on the Pak-Afghan border when returning from Afghanistan and remained imprisoned for almost 17 months (Khatlak-2010). 


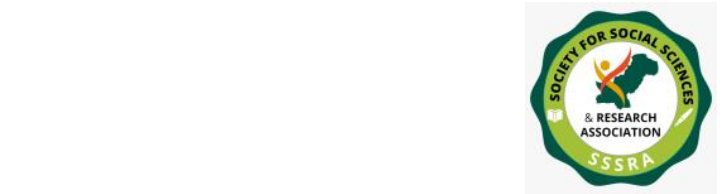

Pak. Journal of Int'L Affairs, Vol 4, Issue 1 (2021)

Causes and Impacts of Terrorism in Swat ...

When he was released from jail, he started a secondary job of chair lift operator in his village. Later on, the starting teaching Quran to the children in a small mosque of his village Mam Dhir (Khan \& Mehmood, 2015). His next move was launching an illegal FM radio station (2004), and this teacher and preacher started giving threats to the government. He was supported financially by the people of surrounding areas (Hussain, 2010). At certain places, he admitted that he was not a religious leader or a scholar but in fact could not stop his movement to get Islamic Sharia enforced in Swat (Khan, Gul \& Sanauddin, 2015). Soon he was given the name of Radio Mullah (Maulana Radio). In 2007 after he became a member of TTP, his organization was known as the terrorist organization of Pakistan. At the end of 2007, his movement was given the name of TTS, which was considered the Swat branch of TTP (Siddique, 2010).

\section{Ideological Factors}

An expert on Swat political affair, Khadim Hussain claimed that Fazalullah transferred the social-political and social-cultural structure of the Swat valley by following the Wahhabi/Salafi Jihadist principle.

Fazalullah motives were purely anti-state, jihad, anti-modernism, anti-women, and extremism (Hussain , 2010). He adopted a very cheap way to spread his superficial dogma to the masses. The illegal FM radio was his mouthpiece to capture the innocent minds of the masses of Swat. He uses to touch their basic and daily issues to get their attention side by side he prepared them for jihad. The followers of his father in law's organization (TNSM) and customary mindsets among Pashtuns supported him a lot. Though his Radio, he pushed the women to fight for their right of inheritance. This was not applicable due to the Rewaj system in Swat. Nevertheless, in this way, he got the support of women who devoted their precious jewelry for jihad. (Khattak, 2010)

\section{Sociological Factors}

Fazalullah propagated against the government of Pakistan and the US to promote his Salafi/ Wahhabi ideology at Imam Deri. He was welcomed and supported by the old followers of TSNM and other natives as he simultaneously favored them in solving their petty disputes according to their wills. He was financially supported by Western countries, local masses and the working class. His centers and madrassas received financial aid from above-mentioned sources. (Hussain, 2010). His followers and supporters kept on multiplying with the passage of time. He stopped the parents from sending their daughter to school. He banned listening to music and watching television as 


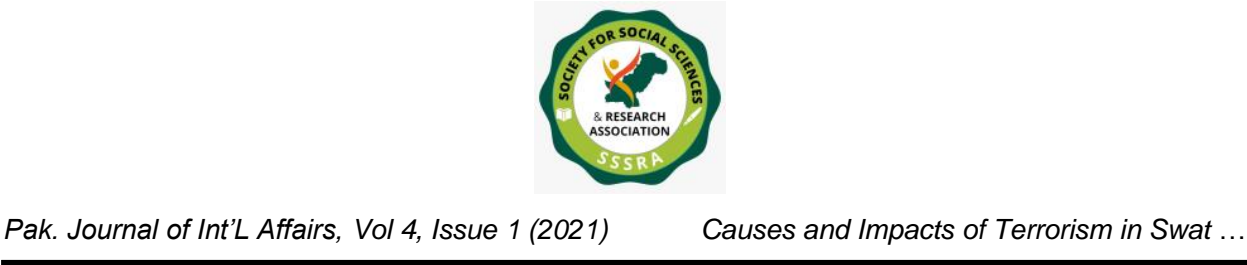

these acts were sinful. He targeted those landlords who did not donate for his cause (Khattak. 2010).

One of the Pakistani analysts stated "Afghanistan has grown up under the shadow of TNSM and its strict version of Islam providing Fazalullah with a ready pool of fighters" (Ali, 2010). His supporters multiplied by the year 2007, His fiery operation changed the minds of the people. At this time, people started setting their TV on fire. Women irrespective of class and class from labor to landlord started donating wheat flour, cooking or cement to brick for the building of grand Mam Dheri Markaz. It was a magnanimous structure for the Taliban to be used for multipurpose activities. He also worked to provide cheap and speedy justice to the region who were fed up with the existing one. People had blind faith in his promises and they dream about the fair justice system of the princely state of Swat (Hussain, 2010). Mullah Khan, one of the analysts said that Fazalullah had a Swati mindset which he used to fulfil his own motives. He says, "More was used to personal rule than democracy or any other form of governance by developing a cult of personnel around them" (Khan\& Seltzer, 2016). Fazalullah accumulated round about 35 million rupees from his followers for Imam Dheri complex which later on was demolished in 2009 by the security forces.

Fazalullah also denounced the polio vaccination campaign across the country. $\mathrm{He}$ stated that the polio vaccination had nothing good for the people instead it was meant to stunt the Muslim population. He considered it to be a Christian and Jews agenda against Pakistan. His followers were also ordered to destroy the ancient Buddha statues and prehistoric carvings on the rocks. Those were granted as unholy and un-Islamism. The TV sets, equipment'spment's, computers, digital cameras, dolls and thousands of similar articles were considered un-Islamic and were put to the rage. The equipment worth millions of rupees were set on fire regarding them the root cause for all kinds of prevailing sins in the society (Nasim and Aziz, 2014). He presented himself as the great preacher of Islam in the Swat region and best replacement for his father-in-law. He followed Sufi Muhammad philosophy by promising people to social equality and quick justice. More jobs and redistribution of property was also on his agenda. People got spellbound under his ex-chanting promises and had faith to get rid of the judicial system which was show and unfair. (Khattak 2010).

\section{Links Between TTP And TTS}

When Fazalullah gained power in Swat in 2000, Malakand division had no signs of the presence of Al Qaida there as TNSM of Sufi Muhammad never endorsed any kind of association with Al-Qaida (Khattak, 2010). The security forces of Pakistan could not find 


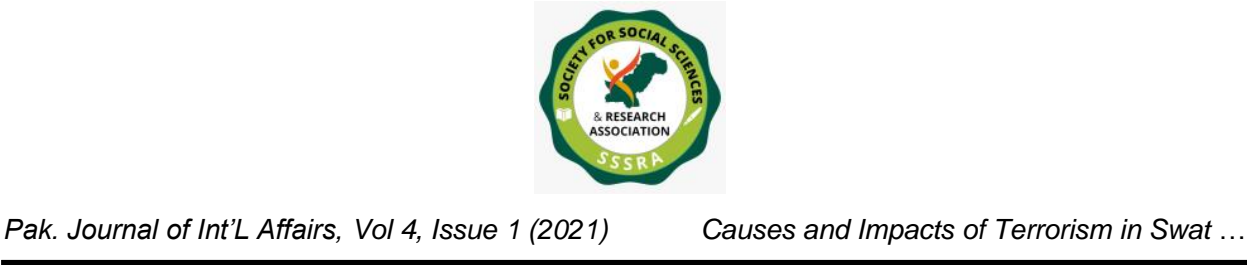

Al-Qaida's presence in Swat-valley. The top leader of Pakistan Taliban, Baitullah Masood founded TTP (Tehreek-I-Taliban Pakistan) in December 2007. It now became the chief Taliban organization of all militant organizations in Pakistan. Mullah Fazalullah was in good terms with the Taliban leader of Afghanistan and the commander of TTP (Tehreek-I-Taliban Pakistan). Their relationships further developed when a grand military operation was started on Jamia Hafsa and Lal Masjid in 2007. Fazalullah, along with a high number of his armed students and followers marched towards Islamabad to support Lal Masjid, mounting pressure to the government either stop the ongoing operation or be prepared for Jihad (Nasim and Aziz, 2014). He started attacking the government and security forces when the government and operation ignored his threats were not abandoned. He stated in an interview, "I just told my followers to be preparjihadr Jihad.

Whatever has started in Swat is not related to the announcement, but it is related to the government operation in Lal Masjid and Jamia Hafsa. It is the responsibility of every Pakistani to rise up in arms against those who are bombing their own people (Siddique, 2010). TTS (Tehreek Taliban Swat) and TNSM had a very strong association with TTP, but Mullah Fazalullah had no authority to make a decision of TTP. The decision making power rested with the TTP leadership in Waziristan (Khattak 2010). All those organizations challenged the writ of government, therefore, the government of Pakistan carried on a serious offensive operation to uproot terrorism on militancy from this valley.

\section{Government Response towards Militancy in Swat}

Government took a lot of actions to eradicate the menace of terrorism from Swat. The deployment of ground forces against the insurgencies of TTP was made sure. A series of military operations conducted in Swat Valley. The initial ones were not successful but the last one Rah-i-Rast became successful.

\section{Operation Rah-e-Haq}

In July 2007 under the directions of the provincial government, the Frontier Constabulary (FC) and police launched an operation against the trained militia force of Fazalullah, but it failed. The Shaheen force formed by Fazalullah gained more strength and power those days and got control of the sub-districts of Fatah purr, Matta, Khwazakhila and Kabul. Swat became a strong platform for all kind of terrorist activities. Targetting government school chiefly girl schools, destruction of government installations, target killing, attacking security forces and suicide bombing was an everyday business in Swat valley. 


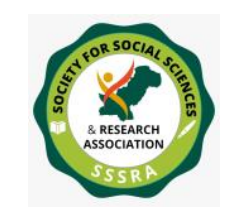

Pak. Journal of Int'L Affairs, Vol 4, Issue 1 (2021)

Causes and Impacts of Terrorism in Swat ...

The deploymarmyof army was directed in August 2007 but when the operation of Lal Masjid took place the situation in Swat became worse. There became an open threat from Fazalullah which further changed into a declaratjihadf Jihad against the government (Hussain, 2011).

In the later months, the TTS became more violent and bigger threat for the security forces and country. They started suicide attacks on the security forces in different areas. They forbade women to go to the market places. At this, a grand operation Rah-IHaq was launched on Oct 242007 against Fazalullah and his militants. At that time Fazalullah had taken their own government system and police stations were under their control. Their titles and names were the institutions like police station had a sign of "Taliban Police Station". On Oct 31 2007, the security forces conducted a minor operation against Fazalullah and claimed 130 casualties of the Taliban but the next day the revenge was taken by Taliban and they attached a military post and killed 50 soldiers. The brutal acts of the Taliban against the security forces were so magnanimous that at the beginning of Nov 2007 most of the policemen resigned from their jobs. Consequently, most of the police stations in the regions of Matta and Khwazakell were empty. TTP's threats to the government persons expanded. At this, the first phase of the operation Rahi-Haq was launched. The whole month of Nov passed and the fight among security forces and Taliban confined. All the buildings were extinct by the Taliban.

They left the control of all government buildings, public places and even their own purpose built main Dheri Markaz, which was Headquarter and Markaz for their activities. Fazalullah run to the mountains along with his followers and students in Dec 2007. It seemed their submission to the security forces but in reality, it was a war strategy (Gunaratna \& Iqbal, 2012). Their secret activities continued till 2008. It was the time when Amway national party (ANP) formed their government in the province (KPK). A report by the provincial government says that since Feb 2008, almost 300 people killed in different combats between the security forces and Taliban s. Among them were 80 army person round about 600,000 affected by the insurgencies of the Militants. The new government of ANP took the office in Feb 2008. This government signed a 16 point agreement with Sufi Muhammad and released him from j21st May May 21, 2008. The agreement had specific conditions for both of the parties. It said that the Taliban would not continue attacking and destroy government installation. They would also stop attaching security forces. In return, the government promised to enforce Sharia law in Swat. Both of the parties considered that their success. Taliban were happy for the implement ion of Islamic law in Swat and regarded it as their victory. At the same time, the government was happy that they restored peace in the region. Both of the parties 


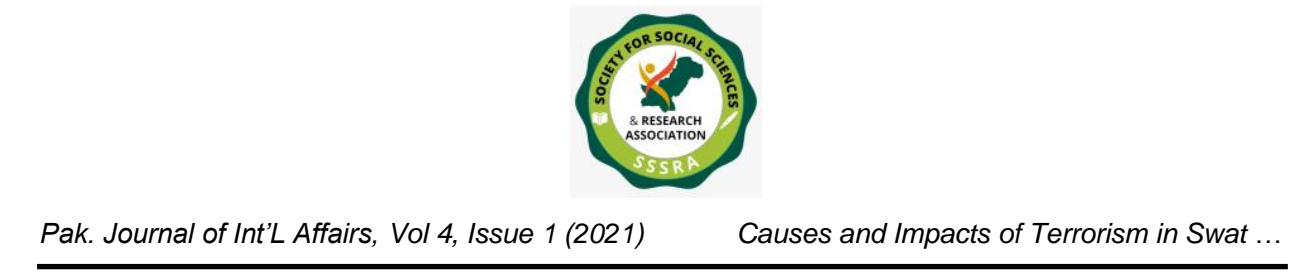

seemed misconception because, on the ground, neither peace was restored nor enforced Islamic Sharia law.

\section{Second phase of Rah-e-Haq}

The 16 point agreement was soon finished between the government and Tehreek-e Taliban Swat (TTS). The government demanded that weapons should be laid down by TTP followers before the forces withdrew from the Swat valley. However, his forces broke the agreement when they attached security forces at the same time. This pact was initially violated by the shaheen force of Mullah Fazalullah when they attacked and slaughtered two junior officers of ISI (Inter-services intelligence) of Pakistan in Matta. In response the Pak Army second phase of Rah-e-Haq launched on Jun 29 2008. Some important and famous Taliban leaders were killed in this operation including Ali Bakht and Tor Mullah. At this, the Taliban's exceeded their insurgencies. They, at the end of June, attacked Pakistan Tourism corporation and destroyed the ski resort Motel of Pakistan in Malam Jabba, attacked a police station, police post, Government installation, educational institutes, girl schools, bridges, and armed forces. Armed forces did massive shelling and carpet bombing on houses, markets, and shops harboring hostile elements.

The most shattering period in the recent history of Swat was the year 2008-2009. Educational institutions were targeted among them were mostly girl schools. Female education was banned, barbers were forbidden to shave the beards of the masses. Television and music were past dreams. About 2 million people were IDP's (Internally displaced people). They migrated from Swat to Mardan, Swabi Peshawar, Lahore, Islamabad and other areas of Pakistan. Only Mingora police station was operational rest of the areas the police stations were evacuated and were not operational. It was estimated that for 5000-6000 militants there was an army of 8000 soldiers who fought against each other in Swat region. The Tehreek Taliban Pakistan (TTP) declared the formation of their government in Swat, they had their own judicial system under which they punished the people on small crimes or bad deeds. The operation against the Taliban by the armed forces created anger among the people. They were displaced due to the operation (Shaheen, 2011).

The ministers and the parliamentarians of ANP did not approve the counter operation by the army. Haji Adeel, the senior ANP senator said about the counterterrorism strategy "What will be the credibility of the military operation in Swat when houses of ministers were destroyed and the family members queued up for shooting" (Yusuf, 2014). He also admitted that the masses had no more confidence in the army and the government. There was no solution to terrorism, and the anti-terrorism war continued 


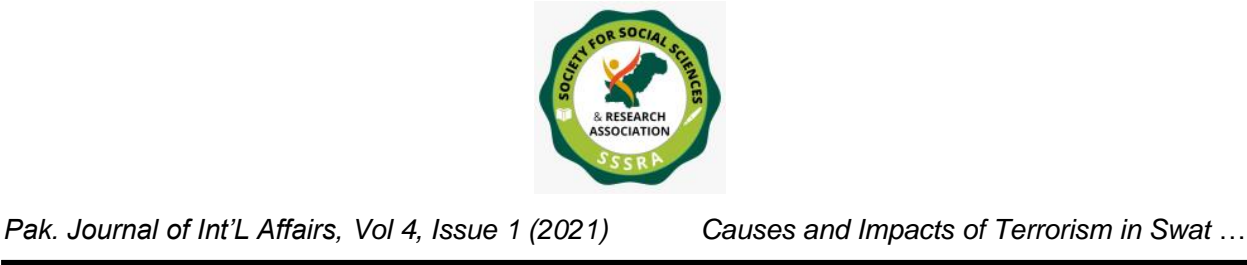

between TTS and the government. The involvement of the national and international actors remained there. Everyone had his selfish motive, but the innocent people of Swat faced the maximum sufferings.

\section{Swat Peace Accord}

Operation Rah-e-Haq phase three was launched in January 2009. Swat was devastated and stood on the verge of a complex disaster. Due to which the government decided another pact with Sufi Muhammad on Feb 15, 2009. The ANP government had to fulfill the demands of the Taliban to enforce Sharia Islamic Law in Malakand and Swat. According to the agreement, the government had to withdraw forces from the valley in a set time frame for which the Taliban had to stop their insurgencies. Militants would lay down the arms. The keeping of personal arms was banned. The suicide bombing was condemned. They were also bound to cooperators with the local police and the security forces. The pact was welcomed and supported by the government of Pakistan.

The president Asif Ali Zardari got the regulation 2009 approved from the federal legislature and passed. This regulation was approving the implementation of Sharia in the valley of Swat. A bizarre reaction was observed from those countries which had no concern with the issues regarding terrorism in Swat. Among them were the US, France, India, Afghanistan, etc. The White House also seemed not happy with the accord and issued the statement, "Violent extremists need to be confronted" (Kronstadt, 2010). Yousaf Raza Gilani, the prime minister of the ruling party, paid no heed to the US concern and responded to it to be an internal affair of Pakistan, and it was the only alternative for the solution of terrorism in Pakistan (Kronstadt, 2010).

Sufi Muhammad returned to Swat after the agreement. He established his camp there and held many rallies in the favor and assurance of peace in the regi18th February Feb 18, and he headed a Grand March to show his coordination with the government in maintaining peace in the valley. Simultaneously Mullah Fazalullah also forbade his supporters to attack the security forces. Later on, Sufi Muhammad kept on putting pressure on the government for the implementation of Sharia otherwise he would break the accord and finish the camp. He was a man of words and everybody knew it and observed/witnessed in the past. After the accord, the FM radio was restarted with much better and improved frequency. This was used to spread his movement in for distant places like Dir, Malakand, and Shangla (Shaheen, 2011).

The situation was worsened when videotape was released showing a young girl being lashed by Taliban who allegedly was involved in immorality. This was very 


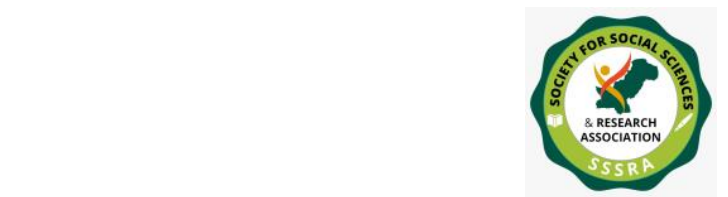

Pak. Journal of Int'L Affairs, Vol 4, Issue 1 (2021)

Causes and Impacts of Terrorism in Swat ...

common in the markets of Swat that CDs of slaughtering of Government servants and army personnel were sold openly. It was further reported that about 24 men and four women were also lashed. It seemed just propaganda to show the brutality of the Taliban. This was demoted by security forces, stated that this was designed propaganda against Pakistan to show her an extremist state (Shaheen, 2011).

Taliban persistently continued to gain strength and expand their influence in the adjacent areas. The state of the affair became bad to be worst when Maulana Fazal-uRahman, the chief of Jamiat-ul-Ulama-e-Islam informed the floor of the assembly that the Taliban had got control to reach Islamabad after crossing Margalla hills. (Kronstad, 2010). The Federal Government denounced the violation of the agreement by the Taliban as they entered Buner and Dir areas. Whereas on the other hand, the Taliban blamed the government for breaking the peace agreement. A commander of Tehreek Taliban Swat announced, "Peace agreement with NWFP government has practically being scrapped, but we are waiting for a word of Maulana Sufi Muhammad for taking the decision" (Tankel, 2013) This argument of the government against this context was also supported by the chief of the joint staff committee. The argument on the issue was in progress when Prime Minister Yousaf Raza Gilani declared another operation against the Taliban in Swat. This operation was named operation Rah-e-Haq (Kumar, 2013).

\section{Operation Rah-e-Rast}

Before initiating the operation Rah-e-Rast, the security forces ordered the masses of Swat to migrate to the safe districts of the region. Around two million people, leaving their native land migrated to safe areas and Relief Providing Zones (RPZs) specifically built for Internally Displaced People (IDPs). The allocated cities were included Swabi, Islamabad, Mardan, Peshawar, Nowshera, and Charsadda. The immigrants or IDPs of Swat had faced a lot of problems in the camps as they had never left their homes before (Ali, 2014). Those people who preferred living in Swat during operation had to suffer differently. They had to stay in their homes for longer periods due to curfews. The food shortage was another big issue. Shortage of water and electricity was the next and so on. The Federal Government guaranteed the continuity of operation until the time they eradicated terrorism from Swat. The Taliban of Swat had complete control over the main towns such as Dagger in Buner and Mingora in Swat (Puri, 2012).

There they set up their own government and marched toward Islamabad to the point that they were only 60 kilometers away. It was a time of great concern for Pakistan and the international community as well. In response to advancement of militants to the major cities, an All Parties Conference (APC) was summoned by the then PM of Pakistan 


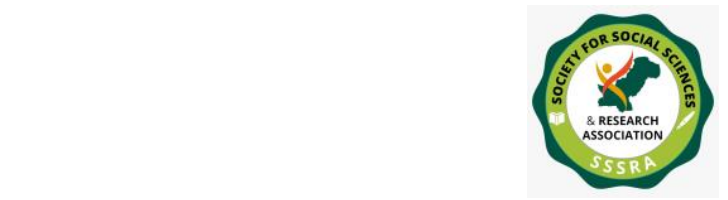

Causes and Impacts of Terrorism in Swat ...

in the capital comprising 43 religious and political parties in representation. The meeting aimed at taking all the parties in confidence about operation against terrorism in Swat and Malakand at large. It was also discussed that the welfare programs for IDPs would be launched and 16 point was agreed upon and signed by the APC (DiOrio, 2016).

Most of the famous commanders of TTS were exterminated whereas the spokesman of TTS, Muslim Khan, was taken in custody in September 2009 (Siddique, 2010). The security forces announced in June 2009 that Swat was completely clear of terrorists. But small incidents happened during the time when IDPs were going back to their homes. There were some reports that the Taliban were active in certain places. In November 2009, another positive sign of peace was seen, and it was the police who took their charges and started normal duty. Mullah Fazalullah was reported to run to Afghanistan (Kronstadt 2010). The military operation Rah-I-Rast proved to be destructive for area as it was kinetic in nature as the strategies deployed did no good for the civil population.

They targeted houses, buildings, and infrastructures. Heavy buildings and shelling devastated the area. It also caused a huge number of casualties in the civil population. Another decision of government to shift people to other areas caused a lot of un-ending problems in the valley (Habib \& Kataria, 2018). It also caused a huge number of casualties in the civil population. Though it was declared by the government and the security forces that the region was cleared of the Taliban and Terrorism was eradicated but this fact cannot be denied that they left their philosophy behind (Habib \& Kataria, 2018). This operation could clear the area from the physical presence of the Taliban but their doctrines, mindsets, and teachings remained behind. Same was witnessed when Shamsher Ali, an ANP leader, was killed in his home by a suicide attacker in Nov 2009 (Khan, Zalan \& Petruzziello, 2018). This incident again created an alarming situation for the people.

In short, the main cause of Terrorism in Swat was a clash of opinion between the government and the Taliban. Taliban's were in favor of TNSM, whereas the government, going against their wills, passed 994 Regulation. Apart from making several agreements, they had a reservation against each other, resulting in wars between both parties. Taliban's of Swat were not very brutal or vigorous until the time when there was an airstrike by security forces in Bajaur Agency on Oct 30, 2006. During this attack, a Madrassa was targeted, where Fazalullah's brother was killed (Khan, 2014).

Taliban activities increased when the operation on Lal Masjid and Jamya Hafsa went a step ahead and joined the leading extremist organization called TTP. For that, they 


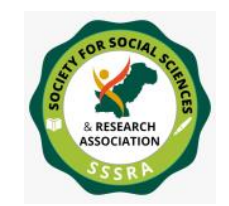

Causes and Impacts of Terrorism in Swat ...

founded a sub-branch called TTS (Tehreek Taliban Swat). Government responded these insurgencies by launching a series of operations to fight back terrorism in Swat. The wiser step would have been by addressing the real issues of the people of Swat. Instead of letting selfish Taliban's to blackmail the masses with shallow promises, the government would have uprooted the cause of terrorism i.e. absence of fair and quick justice system. By solving this single issue the huge devastation could have been prevented. The policeman and government should be vigilant and responsible for repeating such strategic mistakes to avoid any tension in the future

The political instability in Pakistan has been due to three main actors, such as the dictators, weak civilian leadership, and the rising Islamist extremism. The ideology which based and actualized the inception of Pakistan was identity, which made us distinct from the other inhabitants of the subcontinent. After the partition since 1947, Pakistan has been three times by the military dictators ending in a weak political and democratic structure. The political structure of India Pakistan was unbalanced, which resulted in the partition. The same system prevailed in the political system of Pakistan. The internal dynamics of Pakistan politics have been due to the disputes of Kashmir between India and Pakistan. This persistent issue distracted the internal politics of Pakistan (Nasim and Aziz, 2014). The East Pakistan tragedy in 1971, Afghan war and the series of wars in Afghanistan led by the US and other recent operations disturbed the political dynamics. The Islamists have also been challenging the writ of government. They kept on pressuring the government for enforcement of Sharia law and Islamic judicial system.

During the 1980s and 1990s when Afghan war started there has been a lot of discussion regarding the issue. The causes and objectives discussed in different schools of thoughts and on different national and international panels. But undoubtedly, this war created militant mindsets widely. The structure of the Pakistani political system has been constitutional and democratic despite the fact that military rule took over time and again. Further, there have been militancy, regional instability, and Islamization in the state. Another factor is that the establishment of our state has been so flexible to accommodate all kinds of mindsets, struggling for power. The condition has been that they should stay in the constitutional framework. The political structure allows any administered terrorist to enter mainstream politics and the legal system. The responsibility of the establishment is to make sure that rule of law prevails. Democratic institutions should have a policy approach in settling affairs regarding militancy or any uprising rather involve military to solve such issues or to combat internal skirmishes. Another important thing is that a state should have a balanced federation where all federating units are equal stakeholders in the political system. 


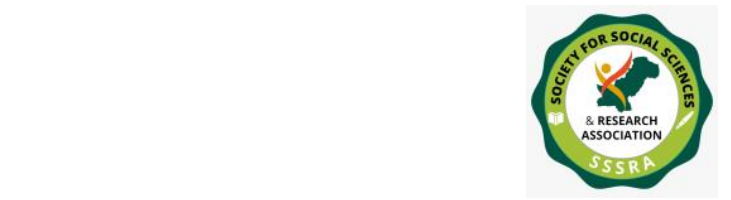

Causes and Impacts of Terrorism in Swat ...

Terrorism and insurgencies in the region of Swat left shocking effects on the lives of the people of Swat. The political life of the region was also deeply influenced. The Political parties had different point of view about terrorism. They adopted different policies and gave policy statement according to their mindset. Among them were those who faced bitter results of their viewpoint due to their policies. Most of them were confused to take part in the political process or discuss the issue of terrorism on any panel as the policies and reactions of the militants were violent. Though with the military operation

TNSM activities were curbed but their signs could be witnessed. Fazallulah also left the area but his supporters remained active and carried on militancy for a longer time. When the restoration of peace was ensured by the security forces even then some of the political families received threats from unknowns (interview with Jaffar shah). These threats were to warn them not to take part in politics and elections. Some individuals and factions suffered as they had no interest in the implementation of Sharia in the region of Swat. Some others fell prey to the ruthlessness of the Taliban's due to their party agenda against the Taliban's. There were multiple reasons which did not please the Taliban's. Resultantly they either targeted the politicians or they terrified them by sending the messages or letters (Rabbi et al, 2018).

\section{The Policies of Awami National Party towards Taliban}

During the movement against British rule, the Indian national congress was working for the liberation of Sub Continent from the British government. But the sympathies for the Hindus revealed their agenda against the Muslims of Sub Continent. Due to this reason the Muslim League was founded to be the mouthpiece for the Muslims of Sub Continent. Khudai khitmatgar Part was a Pashtun non-violent movement against the British Empire which later on joined Congress. Their leader was Khan Abdul Ghaffar Khan known as Bacha Khan. They strongly opposed the partition of sub-Continent. In June 1947 they demanded 'Pashtunistan' an independent state for Pashtuns.

This demand was turned down by the British Empire. Due to this background, they were never liked in Pakistan after the partition. In 1970 the name of the party was changed to the National Awami Party. It was a renowned nationalist fraction of Pakistan. During the 70s, they had excellent relationships with the Union of Soviet Socialist Republic (USSR). They were in bad terms with the establishment of Pakistan on the issue of the Afghani Taliban. In 2008 there became an issue regarding negotiation with the Taliban to bring peace. The Awami National Party (ANP) had a peaceful policy, but for the Taliban's, they had no soft corner. Pak army, on the other hand, was reluctant to ally 


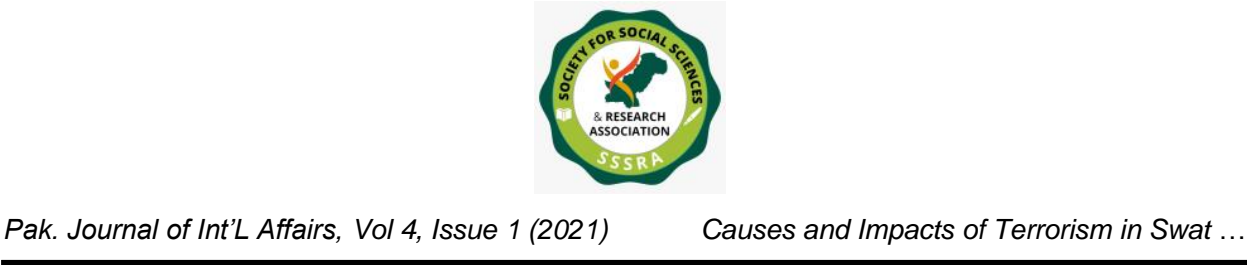

with the United States to start an operation. This was an imposed proxy war. Pakistan had to be the partner in the war due to international pressure.

ANP thus suffered a lot. Their prominent leaders and supporters were killed in Swat and Khyber Pakhtunkhwa by Taliban. This all happened due to their strict policies. After these atrocities, the ANP leadership started to think about changing their policies in Khyber Pakhtunkhwa (Khan, Zalan \& Petruzziello 2018). Terrorism caused very heavy damage to ANP; therefore, they requested for the military operation in Swat. On Aug 19, 2008, the assembly of Khyber Pakhtunkhwa held a discussion in their session to talk about militancy and militant activities. They also demanded policy making for the same. The leadership of the Awami National Party was not on one page. Their leadership had a different point of views regarding the issue of terrorism, especially in the Swat region. One of their leaders, Bushra Gohar, called for the military operation not only to combat terrorism but to stop their activities in the province of KPK. She further emphasized the ISI, the intelligence agency of Pakistan, should clear the land of Pakistan from militant camps ( Khan, Zalan \& Petruzziello, 2018).

The consecutive attacks and killing of the native leaders continued. On Apr 14, 2015, a native leader of ANP was killed in Charsada, and meanwhile, another prominent leader Ghulam Ahmed Bilour was also targeted in Peshawar. This was evidence of invisible rivals of ANP who also disrupted the process of election and successfully turned the results of elections in their favour (Talib, Khan, Kiran \& Ali, 2017).

PPP, ANP, and MQM were those parties that were the main target of Tahreek-iTaliban Pakistan, and the reason was their secular ideologies in the state of Pakistan (Torwali). Pakistan's political ideologies have been confused through fiery rhetoric and opportunism. Therefore, Pakistan has been dominated by a religious extremist mindset. Pakistan's political system has a variety of mindsets and philosophies. Due to collision among their views, consensus could not formed on the issue of terrorism. This is the only point that is absent. Political and national harmony is required to address and curb these issues.

\section{Pakistan Muslim League (N): Policies towards Terrorism in Swat.}

Nawaz Sharifm the chief leader of Pakistan Muslim League (N), remained indifferent to the war on terrorism and the alliance of Pakistan armed forces with the US. This indifference was again shown in 2007 when an unannounced campaign was started against Talibanization. PML (N) was in favor of dialogue with the Taliban against the US strategy against them. Nawaz Sharif was in favor of peaceful settlement of the problem 


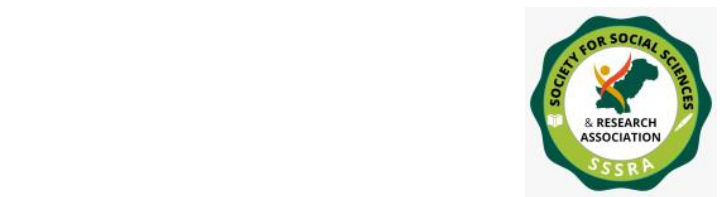

Pak. Journal of Int'L Affairs, Vol 4, Issue 1 (2021)

Causes and Impacts of Terrorism in Swat ...

through table talks. He also promoted the notion to include the supporters of Jamat-eIslami and Taliban in mainstream politics. This policy benefited PML (N) in 2008 elections when Jamat-e-Islami boycotted the elections. The result was that $40 \%$ extra vote bank was received by Pakistan Muslim League $(\mathrm{N})$ which otherwise would have been in Jamat-e-Islami's account. The same policy was adopted by PML (N) in the coming years. No visible step was taken to eradicate insurgency and militancy of the Islamists. This approach won them success and fame among the masses. Thus they succeeded in 2008 elections with a remarkable lead. It was Nawaz Sharif's vision to safeguard Pakistan's interest, unlike Musharraf and Zardari. This was the reason that PML (N) became a popular faction among the people of Khyber Pakhtunkhwa and Punjab.

All above-mentioned reason was the implications of a war against terrorism on the politics of KPK chiefly in Swat. And same was the reason that Pakistan Muslim League $(\mathrm{N})$ got a positive response in the political field of Pakistan. The secular mindsets and the western analysts were of the view that Pakistan Muslim League (N) was a proIslamic party which was expanding distance with the US. The Islamists who were encouraged by Gen Zi- Ul-Haq were again flourishing during PML (N) tenure. There were think tanks who had an opinion that Nawaz was not only breaking up with the United States but also dominating the minds of the peoples of Pakistan. Further, they thought that they were affecting every aspect of society. Despite all views and criticism, Nawaz acted for the interest of his nation and society. He had a perception which could help Pakistan to grow as a strong and independent country. The business class who was supporting Nawaz Sharif knew that Pakistan's economy was mostly depending upon US aid. It seemed unwise to create distance with the US under such circumstances. Their strategy regarding Taliban in Afghanistan seemed somehow the same as Zardari's and Musharraf's. They were at the same time supporting Nawaz Sharif. At the same time, Jamat-e-Islami and the Taliban were supporting Islamic economic revolution and social justice system.

Amid all this situation the law and order in Punjab was under threats. The situation was going from bad to worst. Best effort and strategies had been adopted to tackle the security situation in Punjab. At this, the people realized that the issues created by the Taliban and the demands they had were not the points of concern for the people of Pakistan. They came to the point that they were pushed into the war which was not their war. In March 2010, Shahbaz Sharif made an assertion that Gen Musharraf designed a massacre of the innocent Muslims just to prolong his rule through this. Once the spokesman of PML (N) gave a statement that they were not taking foreign dictation. They added that why the Taliban were involved in terrorist attacks on the land of Punjab 


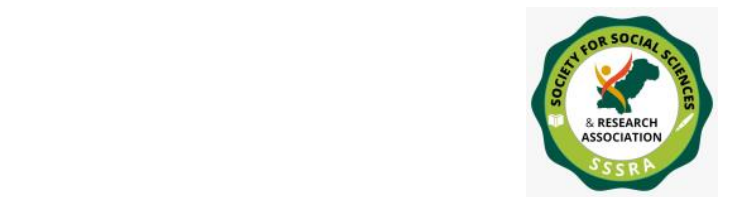

Causes and Impacts of Terrorism in Swat ...

if both were on the same page and were fighting for the same cause. Besides all the efforts PML (N) failed to maintain law and order in Punjab. It was becoming hard to fight back terrorism in Punjab. In July 2010, the shrine of Data Ganj Baksh was targeted in Lahore. It was the worst terrorist attack in Punjab. (Mussarat \& Khan 2014).

If we analyze the provinces of Punjab and Khyber Pakhtunkhwa, we can understand how the politicians from both of the provinces suffered. Those politicians who daringly spoke against the insurgencies were targeted badly. Some lost their political career, and several lost their lives. The militancy and Talibanization had wide-ranging implications on the national politics of Pakistan and the region as well, especially of Swat region. The land of Swat was the epicenter of the terrorist attacks. It was also the Headquarter to plan activities in any part of Pakistan. The politicians could not carry on their political activities due to the threats from the Taliban's side. War on terror was another period which proved to be the nightmare for the people of Swat.

\section{War on terror Discouraged the Political Parties to Participate in 2013 elections:}

Tehreek Taliban Pakistan after strengthening their roots started interfering in the politics. They reacted against the policy statements of the parties or individual politicians. They gave threats to Pakistan Muslim League chairman, Main Nawaz Sharif and his brother Shahbaz Sharif. Some Shia leaders also received the threats. Taliban damaged the smooth political process. Most of the parties, when together gave their words to fight the menace of terrorism but they were fearful and fell prey to insurgencies time and again. When all the political parties were busy in the election campaign, the Taliban at that time were making strategies on how to sabotage the electoral process. For that they targeted many ANP and PPP leaders. The threats were also given to Nawaz Sharif, Shahbaz Sharif 'and Eng. Amir Maqam. All PML (N) leader were also under threat. (An interview with Dr. Shah Muhammad Khan)

Though TTP did not forgive Tehreek-e-Insaf and attacked some of the candidates but did not show any clear resentment against them. It must be PTI's policy regarding the sovereignty of Pakistan. PTI leadership always lashed the US whenever some drone attack was launched inside Pakistan. Pakistan Tehreek-e-Insaf promoted their agenda for peace and the table talks to solve issues. They initiated their effort to negotiate with the Taliban. They made it clear, time and again, that the only solution of extremism in Pakistan is through dialogue with the Taliban. TTP continued its activities in Swat, Malakand and adjacent areas and then they moved forward towards the center. They formed their wings and spread their influence in all parts of Pakistan including Karachi. Their motive there was to finish the political influence of PPP, ANP, and MQM and to 


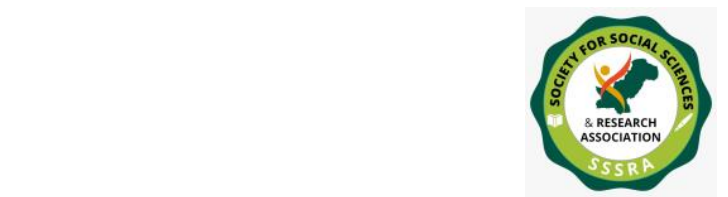

Pak. Journal of Int'L Affairs, Vol 4, Issue 1 (2021)

Causes and Impacts of Terrorism in Swat ...

initiate a militant mindset. In short, they wanted to gain fame before the 2013 elections. They had shown a pleasant attitude towards those factions which changed their political strategies. Parties which were US partner in the war on terror changed their policies regarding the Taliban of Pakistan. The reason behind was they wanted to protect themselves. Many political personalities formed their own parties to achieve some better results including Dr. Abdul Qadeer Khan to resolve the issues in Pakistan. It was assumed by different mindsets that Dr. Abdul Qadeer Khan might be seized by the Taliban to take control over nuclear power or develop their own nuclear weapons to be used against the USA. This fear dominated, and most of the political parties changed their policies and stopped supporting American strategies about anti-terrorism. These parties, which took a big U-turn, were PML (N), PPP, and ANP. This was evidence of these parties' fear of the Taliban. Imran Khan also postponed his rally in Waziristan due to the extreme security threats (Elahi, 2019).

\section{Security Dilemma and Political Participation in District Swat:}

Since the last twelve years, the militancy and terrorism overwhelmed the political scenario of Pakistan. The writ of the state has been challenged, and government machinery paralyzed time and again. The extremist groups have been at war with government machinery. The security forces were their main target, which they repeatedly did. Army personnel's were other frequent target of brutal Taliban. The political killing could also be tracked back in the last decade. It scared and terrified the politicians (Rabbi et al, 2018). The valley of Swat lost enthusiasm for political activities and political participation. The Swat valley, unfortunately, been under the dominance of militants for almost ten years. It was a long period when they executed their own law and hanged army officials publically.

They brutally killed politicians' but a few were spared in this context (Abbasi, 2013). The parties which opposed the Taliban's government in Swat had to face the bitter consequences in the hands of the Taliban. The Taliban considered their parties to be the hindrance for the imposition of sharia law in Swat valley. During their illegal dominance on the Swat valley, they threatened the politicians and they took every brutal step they decided to undertake. Two leaders from various parties suffered and received heavy damage. Taliban have been a very hand upon PPP, away from parties and PML (N) considering them to be part of the government and in operation.

Initially, the Taliban killed supporters, workers, and regional leaders but they did not spare some very important leaders like the assassination of Pakistan People's Party leader Benazir Bhutto and attack on Pervez Musharraf. These assaults and situation in 


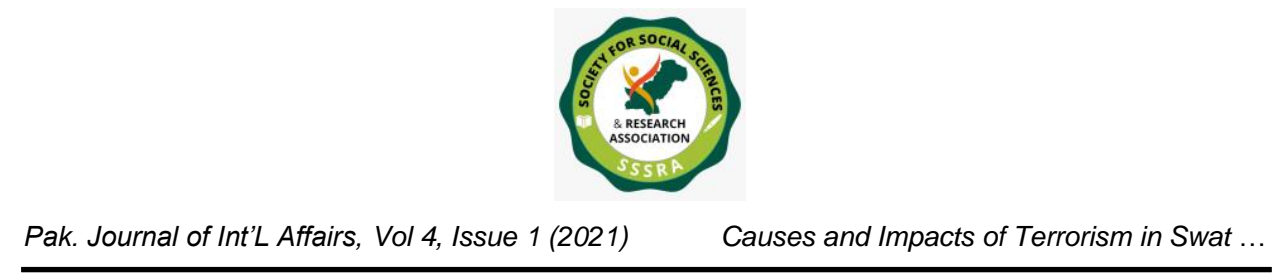

Swat before the war had very features. This kind of insecure condition, the people and positions became doubtful regarding politics. The viewpoint of political parties could not reach them clearly as the representatives of different parties could not hold election campaign or corner meetings. Threats of terrorist attacks prevailed around. The voters were also not free to use their vote in an independent environment. The Awami National Party was on the top of the list for suffering the loss of their valuable representatives and candidates' also states that they could not carry on their election campaign and lost 2013 elections (In an interview with Wajid Ali Khan).

\section{Effects of Terrorism on Sociopolitical Life}

Life in Swat had been a prey to terrorism. All aspects of life suffered and affected. Before annexation of the state of Swat, it had a Jirga system for resolving the issue among Pashtun. Hujra (combine place for guests) in the village was meant for a social gatherings like marriages and funerals. The people of Swat have very strong social bonds and a sense of cooperation during any individual and social problem. There used to be one head for each village called Malak who made decisions and resolved the problems on a daily basis. The Malak was a figure who was supposed to be respected and honored. He was trusted for his advice and his decisions were accepted. He used to be an honorable member of society. The Pashtuns society in the state of Swat was built on these cultural traditions where each member of the society had confidence and faith in these centuriesold norms. There were bonds among Malaks and Khans (people migrated from other areas). But terrorism shattered this traditional society. Pakhtunwali had strengthened the social set up of the region and the people used to partake and ceremonies like marriagfu'ivlafu'ivla with the spirit of cooperation and helpfulness. But all this has vanished, and everything has become ceremonial. The affected area lost socialization people started doubting each other to be spay either for the Taliban or the government.

Certain connections have been found which cause distrust and doubt. In some instances, it has been found that the relatives and real siblings lost trust among themselves. Deep-rooted values which used to be mutually respected, could not hold ground now. Some areas still hold the color of real Pashtun society, especially the regions which were not directly under the control of the Taliban. Those people who were favor of the Taliban were expelled but their families remain in their homes. But some of the ten tans of Khans who strongly supported the Taliban and helped then the killing people could not relearn back to the homes. They thought if they return, they will be consider outcasted would be thrown out of the villages (Elahi 2019).

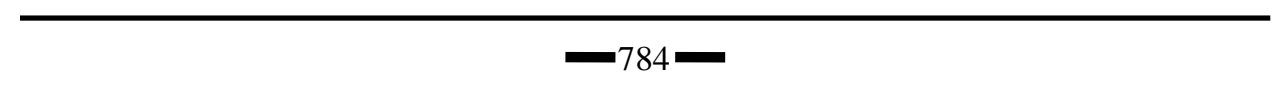




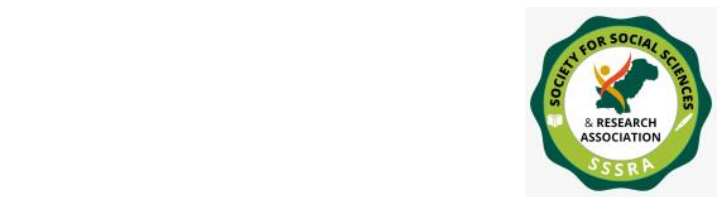

Causes and Impacts of Terrorism in Swat ...

The breakup in the society was mainly due to certain complaints from the poor section of the society or the tenants of Khans. These people had gradients that in the postwar era they were not helped by elders and Khans to standout their feet. Some of the khans migrated in other areas and left their tenants in the hands of the Taliban who forcefully used them for terrorist activities. This caused a rift in Khans and the racial groups of common people. Those people who were depending upon Khan's for their income had become dependent on the Taliban. For jobs, they had to be in Taliban camp. Old political families faded away as they lost attraction among the local people. New young politicians emerged with new trends in politics. Traditional politics was rejected. KhSyed's Syed's families gained power and popularity in the political horizon.

In the election of 2013, the political horizon of Pakistan changed. Tareek-e-Insaf (PTI) gained majority in Khyber Pakhtunkhwa while Awami National Party (ANP) won only one seat in the provincial assembly. That seat was from upper Swat due to candidate deep bonds with the people of the constituency. This area was not under the control of the Taliban. In other areas where ANP lost their seats was due to the complaints and the reaction of the people. They said that these khan's and Malak's left them on the mercy of brutal militants. They took their families to settled and peaceful Pakistan during the uprising. They had shown their anger and reaction in the elections.

\section{Implications on Domestic Security}

The 9/11 incident popularized terrorism nationally and internationally. The internal security was questioned. Due to militancy, a great number of people lost their lives in Federally Administered Tribal Areas (FATA) of Pakistan. The main cause was that these areas were central point or headquarters of Taliban Insurgencies.

To make Pakistan secure and strong, we need to be unified and cooperative. We also need a realistic approach towards leadership with sensible policy whihc can solve the problems regarding security in country. Since Pakistan joint hands on war against terrorism with the US, we have damaged our security on a regional and national level. Though Pakistan was not NATO ally, but was pushed in war by the US. Pakistan's, support did them a lot of benefits but left Pakistan empty-handed. Instead of achieving peace in the region of Afghanistan Pakistan lost her peace and prosperity. Numerouss problems occurred in Pakistan including extremism and insurgency. Security threats had frozen Pakistan from moving on towards progress and prosperity. Apart from this, he could not please the USA, the ally for whom Pakistan accepted this proxy worklist could onto assure the security in any field to make progress. Economic, social, political, educational and other fields are not well protected from militancy and Talibanization. 


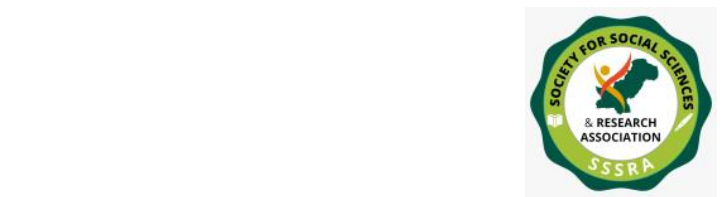

Causes and Impacts of Terrorism in Swat ...

We cannot step forward to modernization and progress in any field as an extremist mindset hinders all institutions. The whole social structure has to please that mindset which is gifted to us during Talibanization. The same security issue prevails in the Swat region. Our security agencies which use conventional methods to fight have threats from Taliban who seems equips with modern weapons and are trained to use modern war strategies. Our security agencies need to be reformed with modern trends and tools. They should be trained and equipped with twenty-first-century war strategies and tactics. We lacked this received heavy casualties in the war against militants. We need to get tanning from developed countries and learn the use of modern weaponry in 21 stcentury wars, which are different and sophisticated.

\section{Regions Extremism Impacts on Judicial Structure in Swat}

In the state of Swat, during the rule of Wali, the administration of justice was one of its prominent features. The Wali could provide timely and fair decisions regarding any issue. The whole structure of society was pro-justice. The provision of justice was lapses free. It was provided to every member of the society without any discrimination with stability and security.

There was no state constitution or any uniformed security forces. The tribal leaders and elders were trained since their birth to be answerable for their conduct under the centuries-old code of conduct known as Pastoral Amal. This code was part of the social set up in all tribes with minor variations' basic concept was the same, i.e., provision of the cheap, timely, and fair justice system for each and every person of the society. The Wali was responsible for establishing Qazi system at village Tehsil and Hakim level. There was an option for the parties, who had a dispute whether to be headed by Qazi or Natural Amal. They also had the right to appeal against the desk in of lower authorities', in this case their appeal was heard by an appointed Islamic scholar known as chief Qazi. Besides this all the officials in administrative institutions were given authority to these parties for their dispute. They could directly take their disputes to the above-mentioned authorities' i.e. Wazir and Wali. In certain high profile cases of political importance, the Wali himself would go to Natural Amal. About judicial hierarchy. Sultan-e-Rome said, "The Qazi courts were subservient to the administrative and the social officers and Islamic laws to a regional code of conduct with both being subordinate to the ruler" (Fleischner,2011).

This spirit of Wali administration has been distributed by Sufi Muhammad and Mullah Fazalullah when they demanded the implementation of Shariat-i-Muhammadi in Swat. The internationally recognized judicial maxim reads "Justice delayed is justice 


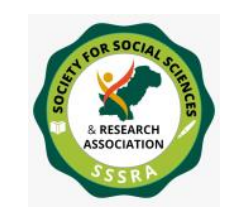

Causes and Impacts of Terrorism in Swat ...

denied". In every society, people demand quick, cheap and fair justice from courts. Provision of which is foremast duty of the government. But unfortunately, in Pakistan, the judicial system has many flaws. Justice is not provided timely. Justice-seeking parties have to wait for a longer period to get their case decided. In certain cases, they have to wait for life. The authenticity of the design also has a big question mark. This make the people lose their trust in the judicial system of Pakistan. The decision of the courts has been controversial in certain cases. This makes people heartbroken and they started trusting the Taliban provinces regarding the provision of justice. Taliban also used this card for their motives.

Popularity among the masses with their slogan of providing speedy justice to Islamic Sharia laws. In this way, they challenged the writ of the government. The government could not fill this gap of the judicial system as per requirement of people. The people of the state had been begging for the same. At last, they stopped expecting this from the government of Pakistan and got enhanced towards the attractive promises of Mullah Fazalullah. Though he declared the establishment of Islamic courts but he could not actualize it in a peaceful manner as they used force and arms to implement their decisions. Killing, beating, whipping and suicide attacks were means to execute their writ. This created an environment of fear and frustration among the common people. The system had no judicial authority or environmental elements to execute law and order. There so called Islamic sharia and Islamic norms were missing. Force and brutality dominated the general environment. The spirit of the Islamic state lies in its welfare projects.

No provision of services, education reforms or any other reality to social or humanitarian relief were present threatens had no structured system or resources to provide public services. That was the reason that they could not entirely with the agreement they signed with the government on May 21, 2008. Before insurgency, disputes were solved by the council of leaders in accordance with the acceptable environmental style.

\section{Talibanization Impacts on Jirga System in Swat}

Jirga system has accepted as a legal system in Pakistani society, which is a team of trusted elders in the level of the village, town, tehsil subdivision or a district level. Each member of a Jirga was esteemed and trusted by the Pashtuns. They had wisdom and knowledge to resolve the problems. The Pashtuns in Pakistan and in Afghanistan had believed in this system. Jirga was formed on the local or regional level in each tribe and area. It was accepted and trusted for centuries. But after the sermons given by Mullah 


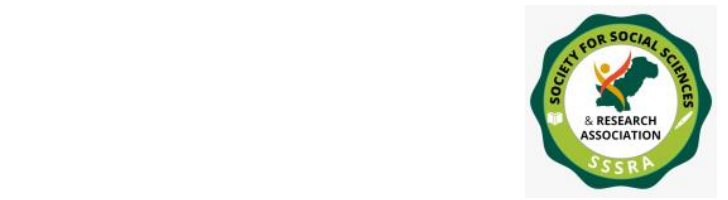

Pak. Journal of Int'L Affairs, Vol 4, Issue 1 (2021)

Causes and Impacts of Terrorism in Swat ...

Fazalullah through FM radio changed the environment and hujra, Jirga courts and government offices have devastated the environment of trust and droughts was created in this centuries in old and strong social setup. This Jirga was trusted for the very important high profile decisions such as in 1917 the selection of Mian Gul Abdul Wadood as the Wali of Swat was the decision made by the Jirga. The decision of making security forces for the protection of Swat and to fight against foreign attacks and the robbers were all done by the Jirga. Walis used to establish Jirgas during their rule.

They used to make decisions according to Islamic and customary law. Rewaj's name (customary law) used to be working as a simplified system in that society. All disputes were decided following the customs by the Jirga (Shinwari, 2011). The members of Jirga were granted authority to make laws in Pashtun Wali (code of inducing), but their power was reduced by Wali after the establishment of formal institutions on the tehsil and district level (Siddique, 2015). The Jirga was still operational in solving petty issues and disputes among the masses on the village level. Some people in Swat stand up in favor of elders; they wanted to call Jira to give the decision to make a Lashkar fight batch the insurgences of Taliban. They wanted to control the Taliban through Lashkar and bring peace. However, people had to stop promoting their view as some elders were killed by the Taliban (Siddique, 2015).

These people also requested to meet and convince the president, Chief Minister and governor of KP to form a Lashkar of local people to fight with the Taliban. But their proposal was not accepted because the Pakistan army never wanted to lose civilians lives. Two noticeable Jirgas has been formed in recent times but were different from the conventional Jirgas of past. One of them was "Swat Qurmi Jirga" led by Rashid khan, an informal head. The purpose of their Jirga was to finalized peace talks among Taliban, government and army officials. Jirga was formed in 2010. This Jirga was meant for a very different purpose then the conventional one, It comprises 200 people from different parts of Swat they had to monitor the distribution of origin and among the affected of terrorism and the proper use of this aid to rebuild the infrastructure. The second Jirga was "Qurmi Aman Jirga" which was headed by team Rehman. This Jirga was only for Katja and the laboring areas (Elahi, 2015). Some committees were also formed in Swat by NGO's and the security forces was called village defense committee (VDC) (Elahi 2015). The aims of these committees were as following:

- To inform security forces in case of any emergencies.

- To find out and inform about the militants who were still involved in activities at the village level.

- To inform the security agencies if someone violated law and order. 


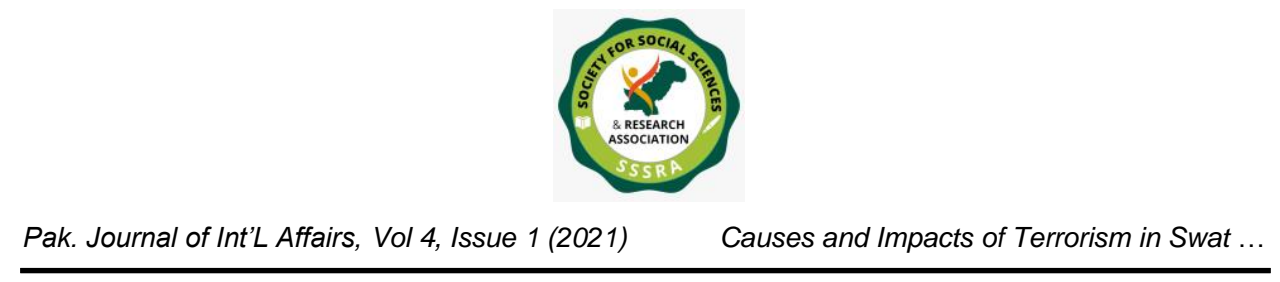

- To have an eye on the strangers who entered any community

- To inform about non-state actors

- To be in touch with security forces they were bound to meet army personals every month to discuss the affairs.

These committees are still working in the area these were set up by national and international originations. All the members belong to the local areas. The aims of these committees are:

- To help employees to communicate local people

- To help to asserts.

- To figure out the deserving people for foreign aid.

- To assembly nature people for various sessions.

- To decide the venue for the gathering of people/meetings.

- To protect the member from the possible attack of local people.

Their committees were meant for those purposes mentioned above. They were not given authority to resolve disputes and issues because they did not belong to the families of landlords. Malaks or other prominent families. They were from the middle class and ordinary people. They had never been accepted as a member of Jirga in old Pashtun society.

\section{Low voters participations:}

Democracy is for the people by the people to the people and for the people. It this main agent is missing how one can continue the democratic and political process. The participation of the masses in the activities has been very limited.

\section{Low Ratio of Educated Youth In Election Process:}

The Taliban mindset would not allow educated minds to be part of politics as they thought that the educated class of the society brought foreign agenda to Pakistan.they thought that educated people were a hindrance to the Islamic judicial and political process. The socioeconomic and political infrastructure was the so-called agenda of the Taliban. They asserted that the only way to provide quick justice to the masses was their version of Islam. Fortified conservative mindset and restricted enlightened liberal people to come forward in politics the Taliban version of socioeconomic development required conventional, extremist mindset. The presence of fear and panic were key points of their society. The liberal narrative in the Swat region and human development stopped in their 


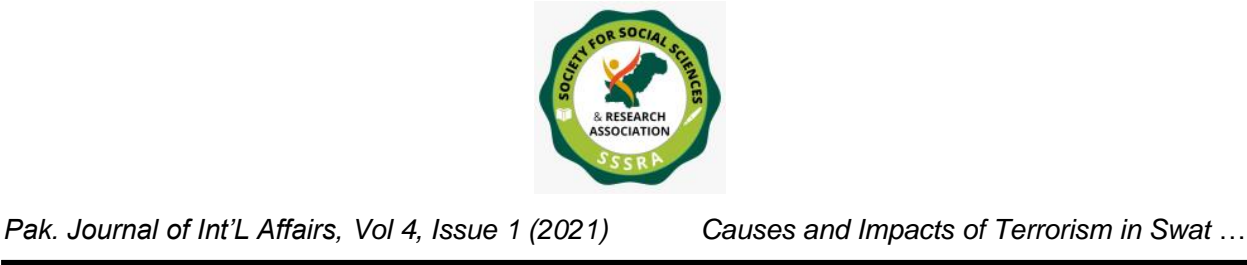

dominance. The spirit of democracy is fresh of speech, which had no place in their version of Islam. They, in other words, pashed the society in darkness.

\section{Women's Right to Vote Restricted:}

In a democratic state, the participation of females in the political process is encouraged. They are more active in modern democracies. They are considered the national builders. They can demolish a nation as well. They are actively participating as members of parliament and political leaders as well. Women participation in other activities was forbidden to think to join mainstream politics was an unthinkable

\section{The decrease in political meetings and rallies:}

It is considered that the gatherings and rallies are a reflection of political enthusiasm. The contestants hold meetings and rallies daily to attract their voters towards their party manifesto. However, the case in Swat was very different. They could not come out of their houses. Both positions and voters have restricted due to terror and fear of Taliban. Another factor was a restriction by security forces tpeople'seople's lives in terror attacks on the crowds.

\section{Conclusion}

Swat valley became a hub of TTP of Pakistan after the breakdown of war on terror, and there was a brutal assault of Swati people Taliban's on the name of Islamization. This destroys the peace and beauty of the valley, and fear among the people have been observed as they can not breathe. Thus, the government started operations name Rah-eRast and Rah-e-haq phase one and two with the narrative to destroy the terrorist network and maintain peace in Swat like before as Swat is one of the tourist places and have natural sceneries as well. However, terrorist influence disables the life of Swati people. They announced women could not move out even for studies, they butchers man and hang their bodies in the middle of roads to terrify people on the man of Islamization. Women were forced to cover themselves with Burqah. Women were deprived of casting votes, and TTS and TTP destroyed the law and order system. They imposed their law on the name of shariah. It took almost one decade to maintain peace in Swat, and thousand of people lost their lives, including civilians and military personnel. Now Swati people started living their normal life, but terrorist hold on their land will always remain as a nightmare in their lives. 


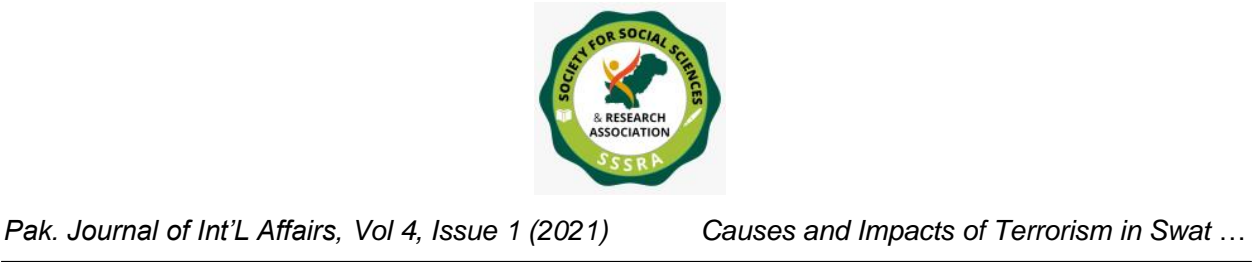

\section{References}

Abbasi, N. M. (2013). Impact of terrorism on Pakistan. Strategic Studies, 33(2).

Ali, A. (2010). The economic cost of terrorism: A case study of Pakistan. Strategic Studies, 30(1-2).

Ali, A. (2014). The use of information and communication technologies for improvement of proceedingsin district judiciary of Khyber Paktunkhwa, Pakistan (Doctoral dissertation, Hazara University, Mansehra).

DiOrio, D. R. (2016). The Implementation of Governance to Counter Islamist Militancy in Pakistan's Khyber-Pakhtunkhwa Province.

Elahi, N. (2019). Terrorism in Pakistan: The Tehreek-e-Taliban Pakistan (TTP) and the Challenge to Security. Bloomsbury Publishing.

Fleischner, J. (2011). Governance and militancy in Pakistan's Swat valley. Center for Strategic and International Studies.

Gunaratna, R., \& Iqbal, K. (2012). Pakistan: Terrorism ground zero. Reaktion Books.

Habib, Z., \& Kataria, J. R. (2018). Factors Affecting Performance of Primary Schools Teachers in Terrorism Affected Areas: A Case of District Swat. South Asian Studies (1026-678X), 33(2).

Hussain, S. (2016). Media Treatment of the Internally Displaced Persons from Swat. Global Media Journal: Pakistan Edition, 9(1).

Hussain, S. E. (2010). Terrorism in Pakistan: Incident patterns, terrorists' characteristics, and the impact of terrorist arrests on terrorism.

Khan, A. J., \& Mehmood, T. (2016). The Role of Informal Institutions in Conflict: an Assessment Study in Swat, Pakistan. Journal of Global Peace and Conflict, 4(2), $1-19$.

Khan, A. J., \& Mehmood, T. (2016). The Role of Informal Institutions in Conflict: an Assessment Study in Swat, Pakistan. Journal of Global Peace and Conflict, 4(2), $1-19$. 


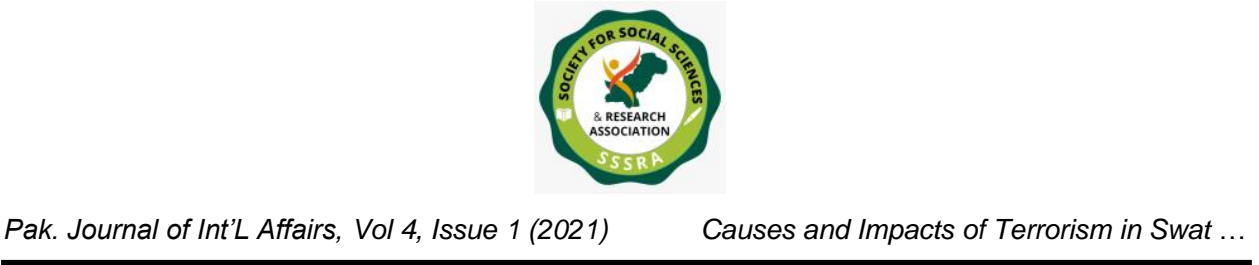

Khan, J. (2014). Combating Militancy: A Case of Pakistan Military Operations. London: British Research Institute.

Khan, N. U., Zalan, A., \& Petruzziello, A. (2018). Suppl-1, M4: Determining the Actual Prevalence of Hepatitis B in Khyber Pakhtunkhwa-Pakistan: A MetaAnalysis. The open virology journa,l, 12, 33.

Khan, S., \& Seltzer, A. (2016). The Impact of Fundamentalist Terrorism on School Enrolment: Evidence from North-Western Pakistan, 2004-09.

Khan, Z., Gul, S., \& Sanauddin, N. (2015). Bakunin Model of Anarchism and Militancy in Swat, Pakistan. Pakistan Journal of Criminology, 7(1), 61.

Khan, Z., Gul, S., \& Sanauddin, N. (2015). Bakunin Model of Anarchism and Militancy in Swat, Pakistan. Pakistan Journal of Criminology, 7(1), 61.

Kronstadt, K. A. (2010, June). Pakistan: Key current issues and developments. LIBRARY OF CONGRESS WASHINGTON DC CONGRESSIONAL RESEARCH SERVICE.

Kumar, S. (2013). Pakistan's Internal Security 2009. In India's National Security (pp. 310-330). Routledge India.

Nizami, A. T., Hassan, T. M., Yasir, S., Rana, M. H., \& Minhas, F. A. (2018). Terrorism in Pakistan: the psychosocial context and why it matters. BJPsych international, 15(1), 20-22.

Puri, S. (2012). Pakistan's war on terrorism: strategies for combating jihadist armed groups since 9/11. Routledge.

Rabbi, F., Ali, A., Ali, S., \& Khan, A. (2018). Doing Business under Terror: Empirical assessment of Hotel Business in the Post Conflict Period in Swat valley, Pakistan. NICE Research Journal of Social Science. ISSN: 2219-4282, 7(14), 1128.

SHAHEEN, D. A. (2011). THE EMERGENCE OF CONFLICT IN SWAT VALLEYAND THE POST-CONFLICT MANAGEMENT ISSUES.

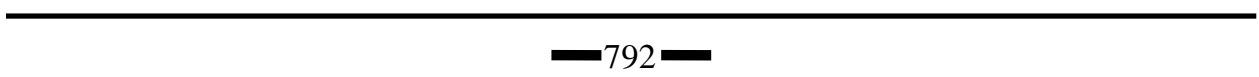


Shinwari, N. A. (2011). Understanding jirga: Legality and legitimacy in Pakistan's federally administered tribal areas. CAMP.

Siddique, O. (2015). The Other Pakistan: Special Laws, Diminished Citizenship and the Gathering Storm. Norms, Interests, and Values: Conflict and Consent in the Basic Constitutional Order, 2, 249.

Siddique, Q. (2010). Tehrik-e-Taliban Pakistan: An attempt to deconstruct the umbrella organization and the reasons for its growth in Pakistan's north-west (No. 2010: 12). DIIS Report.

Talib, N., Khan, J., Kiran, A., \& Ali, R. (2017). Antecedents and consequences of job satisfaction: Evidence from hospitals of Khyber Pakhtunkhwa (KPK). Journal of Research in Social Sciences, 5(1), 83.

Tankel, S. (2013). The militant groups next door. Foreign Policy, 24.

Yousaf, F. (2014). Master of Public Policy (Doctoral dissertation, University of Erfurt). 